\title{
LIMITATION OF THE RIGHT TO REQUIRE ENFORCEMENT UNDER THE RULE OF THE NEW CIVIL PROCEDURE CODE OF AN ENFORCEMENT ORDER OBTAINED BEFORE ITS ENTRY INTO FORCE
}

\author{
C.-A. Domocoş
}

Carmen Adriana DOMOCOȘ, University of Oradea

Faculty of Law, *Correspondence: Carmen Adriana Domocos, University of Oradea, Faculty of Law, 26 General Magheru, Bihor, Romania

E-mail: carmendomocos@gmail.com

\begin{abstract}
In a case, the court of appeal have interpreted the provisions of the law regarding the enforceable judgments delivered at first instance, with the right of appeal, or those in respect of which the parties agreed to directly exercise the appeal, when those interested or harmed by the enforcement can require the cancellation of the enforcement documents drawn up by violation of the legal provisions. The jurisprudence is not unanimous to consider the enforceability of the final civil decision is, however, a temporary one, until it is confirmed by the court of appeal, and it is removed when the court of appeal gives a contrary approach.

One of the roles of the limitation is to provide the security of legal relationships, because after the expiry of the limitation period the debtor is satisfied that it can no longer be enforced, and the creditor knows that he no longer benefits from the coercive force of the state in order to recover his debt. On the other hand, to oblige the creditor to enforce a temporarily enforceable decision, about which he has no certainty that it will be upheld on appeal, means violating the very principle of the security of legal relationships, which the legislator intended to protect.
\end{abstract}

KEYWORDS: limitation the period, enforcement of the judgment, appeal, claim

\section{INTRODUCTION.}

The role of the jurisprudence is very important in the interpretation of those provisions of the law which are not clear enough. There is still a dispute regarding the enforceable judgments delivered at first instance, without right of appeal, or those in respect of which the parties agreed to directly exercise the appeal, when those interested or harmed by the enforcement can require the cancellation of the enforcement documents drawn up by violation of the legal provisions, if they can invoke substantive defenses against the enforcement order which is not issued by a law court or if they can invoke exceptions in this framework.

\section{CHAPTER I.}

By civil decision no. 11107/2015 of Oradea Law Court, it was partially upheld the appeal against enforcement filed by the appellant against the appellee SC E SA, and consequently it was partially annulled the conclusion for determining the costs of enforcement no. 1 as at 22.09.2015 within the enforcement file no. 608/2015 of B.E.J. Gîrdan Marius Florin, in that it has been ordered the reduction of the costs of enforcement as follows: service of procedural documents from 496 lei to 24.8 lei, consultations relating to the making up of the enforcement 


\section{LIMITATION OF THE RIGHT TO REQUIRE ENFORCEMENT UNDER THE RULE OF \\ THE NEW CIVIL PROCEDURE CODE OF AN ENFORCEMENT ORDER OBTAINED BEFORE ITS ENTRY INTO FORCE}

file from 248 lei to 24.8 lei and bailiff's fees from 2513.48 lei to 571.07 lei; there were kept the other enforcement documents and the other costs of enforcement established by conclusion no. 1 as at 22.09.2015.

The court rejected the appellant's application for annulling the enforcement itself; it bound over the appellee to pay the appellant the sum of 200 lei representing court fees consisting of lawyer's fees; It rejected the appellant's application for reimbursing the legal stamp duty because it was prematurely brought; It recorded that the appellee did not request any court fees.

In order to deliver this judgment, the trial court concluded the following:

\section{CHAPTER II.}

By civil decision no. 1776/02.02.2012 delivered in case no. 8950/271/2005* by Oradea Law Court, final through Civil Decision no. 1017/R/02.12.2014 of Bihor Law Court, it was upheld the application for returning the enforcement, the appellant being required to reimburse the appellee the sum of 12.651 lei brought up-to-date with the inflation rate from the date of receipt until the date of reimbursement. From civil decision of Oradea Law Court, it results that the sum in question was paid by the appellee to the appellant under civil decisions no. 830/C/2003 and no. 791/C/2004 of Bihor Law Court. These judgments were changed by decisions no. 320/2005 and no. 321/2005 of the Court of Appeal of Oradea.

\section{CHAPTER III.}

By application no. 4513/14.08.2015, registered at BEJ Gîrdan Marius Florin on 21.08.2015 in the enforcement file no. 608/E/2015, the appellee filed an application for the enforcement of judgments for the sum of 20144.95 lei, representing: 18908.95 lei compensation payments made under Government Emergency Ordinance no. 98/1999 brought up-to-date with the inflation rate until 31.03.2015 and 1236 lei undue court fees representing the expert's fee.

Being the second phase of the civil trial, enforcement shall take place in strict compliance with the provisions of Art. 622 et seq. of the Civil Procedure Code. The violation of such provisions opens for the interested party the opportunity to file an appeal to enforcement by which there can be invoked, in principle, only the aspects related to the alleged irregularities committed by the representative of the public force.

Within the appeal to enforcement, according to Art. 622 et seq. of the Civil Procedure Code, those interested or harmed by the enforcement can require the cancellation of the enforcement documents drawn up by violation of the legal provisions, they can invoke substantive defenses against the enforcement order which is not issued by a law court and they can invoke exceptions.

According to Art. 632 paragraph 1 of the Civil Procedure Code, the enforcement can be made only pursuant to an enforcement order, and according to paragraph 2, there are enforcement orders the judgments under Art. 633, judgements with provisional enforcement, final decisions and any other decisions or documents which, according to the law, can be enforced. Art. 633 point 2 of the Civil Procedure Code states that there are enforceable judgments the judgments delivered at first instance, without right of appeal, or those in respect of which the parties agreed to directly exercise the appeal, according to Art. 359 paragraph 2. 
Also, according to Art. 663 paragraph 1 of the Civil Procedure Code, the enforcement cannot be done unless the claim is certain, liquid and due.

On the other hand, Art. 706 of the Civil Procedure Code provides that the right to obtain enforcement shall be prescribed within 3 years, unless the law provides otherwise, and that the limitation period shall begin from the date when it is given the right to obtain the enforcement, in case of judgments, the limitation period starting from the date they remain final.

According to Art. 3 paragraph 1 of Law no. 76/2012, the provisions of the Civil Procedure Code of year 2009 shall apply only to trials initiated after its entry into force. As a result, the nature of civil decision no. 1776/02.02.2012 and the limitation of the enforcement of judgments within the case no. 8950/271/2005* shall be governed by the Civil Procedure Code of year 1865.

Civil Decision no. 1776/02.02.2012 is final, according to Art. 377 point 1 of the Civil Procedure Code of 1865 and enforceable, in accordance with Art. 376 paragraph 1 of the Civil Procedure Code of 1865, and the appellant's appeal did not suspend the execution of the civil decision, according to Art. 300 paragraph 1 of the Civil Procedure Code of 1865. Art. 405 paragraph 2 of the Civil Procedure Code of 1865 provides that the limitation period shall begin from the date when it is given the right to require enforcement.

From the perspective of the limitation, the court concluded, in agreement with the appellant, that the moment when the limitation period starts is given by the acquisition of the enforceability of the enforcement order. Since the Civil Decision no. 1776/02.02.2012 of Oradea Law Court was delivered under the Civil Procedure Code of 1865, it results that there are applicable to it, in terms of acquiring the enforceability or not, the provisions of the law under which it was delivered, according to the principle of non-retroactivity of civil law provided in Art. 15 paragraph 2 of the Romanian Constitution, Art. 1 of the Civil Code of 1864 and Art. 6 of the New Civil Code. Therefore, being final, having the possibility only to be appealed, it results that the decision was enforceable and could be enforced voluntarily, even since 02.02.2012. This principle is also reiterated by Art. 27 of the Civil Procedure Code of 2009, applicable in this case from a procedural point of view, showing that judgments remain subject to appeal, to the grounds and terms provided by the law under which the trial began.

The enforceability of the final civil decision is, however, a temporary one, until it is confirmed by the court of appeal, and it is removed when the court of appeal gives a contrary approach.

One of the roles of the limitation is to provide the security of legal relationships, because after the expiry of the limitation period the debtor is satisfied that it can no longer be enforced, and the creditor knows that he no longer benefits from the coercive force of the state in order to recover his debt. On the other hand, to oblige the creditor to enforce a temporarily enforceable decision, about which he has no certainty that it will be upheld on appeal, means violating the very principle of the security of legal relationships, which the legislator intended to protect.

There are often situations in which decisions are changed in the appeal, and a cautious creditor prefers to wait to be given irrevocable right not to get in the situation where the performance was to be cancelled and returned, with the consequence of not recovering the costs of enforcement and of being obliged to bear the costs. In addition, it would generate many trials having as object appeals to enforcement and return of enforcement, or, the legislator did not intend to burden the court dockets. 


\section{LIMITATION OF THE RIGHT TO REQUIRE ENFORCEMENT UNDER THE RULE OF \\ THE NEW CIVIL PROCEDURE CODE OF AN ENFORCEMENT ORDER OBTAINED BEFORE ITS ENTRY INTO FORCE}

In this case, the appellee has enforced a civil decision, final and enforceable, paying into the appellant's and other former employees' accounts the amounts which she was obliged to pay, but the legal relationship was completely changed on appeal. She led to the making up of case file no. 8950/271/2005* having as object the returning of enforcement, where in 2012 more than one hundred individuals were required to repay the appellee the amounts received in 2004, with court fees. It is an example of the negative effects that may occur by the enforcement of a decision for which no remedies have been exhausted.

As regards the limitation, we should distinguish between the substantive right of action and the right to require enforcement, as in the first case we deal with a substantive civil law, while in the second case we deal with a procedural civil law, each subject to the specific rules of law, or civil law in the first case, and civil procedural law in the second case. In the first case, there is applied the substantive civil law governed by the New Civil Code, as in this case, by reference to the moment when the first judgment was delivered, 02.02.2012, when it was given the right to action, this being the time of acquisition of the enforceable nature of the order enforced, and in the second case there are applied the provisions of the Civil Procedure Code of 1865, in relation to the same moment, 02.02.2012.

The limitation of the right to request enforcement cannot begin as long as the interruptive effect of the writ of summons is not definitively consumed and the substantive right to action is not exhausted (Art. 2537 et seq. of the Civil Code, and previously, Art. 16 and 17 of Decree no. 167/1958), namely until the judgment for upholding the action has not been in res judicata.

Moreover, Art. 1868 of the Civil Code of 1864, under which it started the whole dispute that was the object of case no. 8590/271/2005* (taken over by the current regulation by Art. 2539 of the Civil Code.), provided that an application cannot interrupt the limitation, only if it is permitted by the law court by judgment with irrevocable authority. In this case, no limitation could begin after the filing of the writ of summons and until the delivery of such a judgment. In relation to the above, the court considered that by the establishment of the enforceability of the final civil decisions, the legislator in 1865 intended only to enable the creditor who was in a state of emergency to obtain the enforcement of his claim, and not to defraud for the effects of a judgment the cautious creditor who preferred to wait for the irrevocable solution in order to avoid the costs and the involvement in other trials. Therefore, by the provisions of Art. 405 paragraph 2 of the Civil Procedure Code, the legislator had in mind as the moment for beginning the limitation the final entitlement to require enforcement. The appellee's right of claim was finally given when delivering Civil Decision no. 1017/R/02.12.2014 of Bihor Law Court, in relation to which the limitation was not fulfilled on the date of appealing to the enforcement body.

In conclusion, in the case of the judgments, limitation of the right to request enforcement always begins from the date on which it becomes irrevocable. The beginning of the limitation shall not be linked to the enforceability or non enforceability of the judgment, but to its res judicata.

As for the date on which the judgment to be enforced became irrevocable, it is, in this case, in the moment when it was delivered by the court of appeal, 02.12.2014.

Given the fact that the enforcement application was registered on 21.08.2015, at less than a year as from the date of delivery of the judgment in the appeal, the court concludes that it was 
delivered during the limitation period, so that the court shall expel the appellant's allegations on the illegality of the enforcement in the enforcement file no. 608/2015 of B.E.J. Gîrdan Marius Florin.

By the conclusion as at 22.09.2015 the bailiff established following costs of enforcement: 1.5 lei for mail envelope, 17 lei for C.N.P.P. fees, 20 lei for town hall fee, 49 lei for postage fees, 124 lei for material expenses under Art. 670 paragraph 2 point 7 of the Civil Procedure Code, 496 lei for the service of procedural documents, 248 lei for consultations relating to the making up of the enforcement file, and 2513.48 lei for the bailiff's fee.

According to Art. 669 paragraph 4 of the Civil Procedure Code, the sums fixed by the bailiff, including his fee, may be censored by the court by way of appeal against enforcement, taking into account the evidence administered.

The bailiff set the maximum fee for the service of procedural documents and for indirect enforcement. Given the fact that the bailiff was given at the same time several cases based on the same enforcement order, and thus he issues common addresses or notifications to the public institutions and banks, and that in the case it is done enforcement concerning movables, the court considered that it is enough the minimal fee, and therefore it ordered the reduction of the costs of enforcement as follows: service of procedural documents from 496 lei to 24.8 lei, consultations relating to the making up of the enforcement file from 248 lei to 24.8 lei and bailiff's fees from 2513.48 lei to 571.07 lei, the sums including VAT.

Material costs and those on the fees were maintained at the level set by the bailiff. For the reasons above, under Art. 720 of the Civil Procedure Code, the court upheld in part the appeal to enforcement, according to the dispositions.

According to Art. 453 paragraph 2 of the Civil Procedure Code, the court bound over the appellee to pay the appellant the sum of 200 lei representing court fees consisting of lawyer's partial fees, according to receipt filed (f.37) and it rejected the appellant's application to oblige the appellee to pay the court fees consisting of the legal stamp duty, given the provisions of Art. 45 paragraph 1 subparagraph $f$ and paragraph 2 of Government Emergency Ordinance no. $80 / 2013$, the appellant having the possibility to require the reimbursement the legal stamp duty proportionally to the upholding of the appeal, after a final judgment.

IV. The appellant made an appeal against this judgment, requesting the upholding of the appeal, the changing of the civil decision no. 11107/2015 of Oradea Law Court, having as consequence the upholding of the enforcement appeal brought against the acts of enforcement and the enforcement itself that is the object of case no. 608/2015 of BEJ Gîrdan Marius Florin and the cancellation of the enforcement following the expiration of the limitation period of the right to obtain enforcement in accordance with the provisions of Art. 706-707 of the Civil Procedure Code in relation to Art. 376-377 of the Civil Procedure Code of 1865. There were charged court fees.

As grounds for the appeal, it is stated that by the appeal against the enforcement filed by the appellant SC. E. Oradea S.A., the court was requested to declare as fulfilled the limitation period of the right to obtain enforcement, under the following considerations:

The enforcement order which is the object of the enforcement of the enforcement file 497/2015 of BEJ Gîrdan Marius Florin is represented by the Civil Decision no. 1776/02.02.2012 of the Law Court of Oradea, becoming irrevocable by Civil Decision no. 1017/R/02.12.2014 of Bihor Law Court, both being delivered in case no. 8950/271/2015*.

Civil Decision no. 1776/02.02.2012 of the law court of Oradea is a final judgment, this character being due to the incidence of the provisions of the Civil Procedure Code of 1865 
and the fact that the judgment in question was delivered without right to appeal, which in accordance with the provisions of Art. 377 point 1 of the Civil Procedure Code of 1865 led to becoming a final judgment.

According to Art. 376 of the Civil Procedure Code of 1865, and given the final Civil Decision no. 1776/02.02.2012, this judgment was enforceable as from the time of it was delivered, and it could be put into enforcement.

According to Art. 706 of the Civil Procedure Code, the right to obtain enforcement shall be prescribed within 3 years, unless the law provides otherwise, the limitation period beginning from the date when it is given the right to obtain the enforcement. Thus, given the procedural provisions in force at the time of delivery of Civil Decision no. 1776/02.02.2012, respectively Art. 376 and Art. 377 of the Civil Procedure Code of 1865, the right to obtain enforcement was given at the time of delivery of Civil Decision no. 1776, namely on 02.02.2012.

Following the filing of the application for enforcement by the creditor S.C. E. S.A. on 21.08.2015 it shall be found to be fulfilled the limitation period of the right to obtain enforcement. Therefore:

Generally, the court of appeal is requested to find out the fact that based on the legal norms mentioned above, Civil Decision no. 1776/02.02.2012 has become final and enforceable as from the date of its delivery namely 02.02 .2012 , in this case being irrelevant the fact that, after passing the appeal, Civil Decision no. 1776 became irrevocable by delivering the Decision 1017/R/02.12.2014, as long as the right to obtain enforcement was given on the date of delivery of Civil Decision no. 1776/02.02.2012 and not on the date when it became irrevocable.

Specially, even where it would be calculated the date when the right to obtain enforcement was given as from the time when Civil Decision no. 1776/02.02.2012 became irrevocable, it shall be found out that in relation to the appellant, Civil Decision no. 1776/02.02.2012 became irrevocable at the expiry of the period to make an appeal due to the fact that he did not appeal against the Civil Decision 1776.

Thus, the court of appeal is requested to find out that the appellant acted as an appellee within the appeal against the judgment in question, as it results from Decision no. 1017/R/02.12.2014 delivered in case 8950/271/2005*, and thus in relation to her, Civil Decision no. 1776/02.02.2012 became irrevocable at the latest on the date on which the appeal was made against her, namely 18.04.2012.

As regards Civil Decision no. 10916/03.12.2015 delivered by the Law Court of Oradea in case 14934/271/2015, it is considered to be unfounded for the following reasons:

The first instance finds out that the Civil Decision no. 1776/02.02.2012 is final according to Art. 377 point 1 of the Civil Procedure Code of 1865 and enforceable in accordance with Art. 376 of the Civil Procedure Code of 1865 and the appeal made in this case did not suspend the execution of the civil decision according with Art. 300 of the Civil Procedure Code of 1865, but it considers that "the enforceability of a civil decision is temporary, until the confirmation thereof by the court of appeal" and "to oblige the creditor to enforce a decision which is temporarily enforceable, about which he is not sure that it will be upheld on appeal, means violating the very principle of the security of legal relationships, which the legislator intended to protect." 
In relation to these conclusions of the trial court, it is considered that "by the establishment of the enforceability of the final civil decisions, the legislator in 1865 intended only to enable the creditor who was in a state of emergency to obtain the enforcement of his claim, and not to defraud for the effects of a judgment the cautious creditor who preferred to wait for the irrevocable solution in order to avoid the costs and the involvement in other trials."

In essence, the trial court recognizes the final and enforceable nature of the Civil Decision no. 1776/02.02.2012 but assigns it a provisional attribute, arguing that the limitation period of the right to obtain enforcement does not start on the date on which there is given the right to require enforcement, but from the time when the Civil Decision no. 1776/02.02.2012 cannot be reformed anymore or when it becomes irrevocable.

The appellant considers the conclusions of the trial court as being absolutely unfounded, the first instance building its argument by adding to the law and by removing the unequivocal provisions of legal norms incident in the matter, legal norms linking the start of the limitation period to the time when there was given the right to require enforcement, right which is given by the final and enforceable nature of civil decision no.1776/02.02.2012, acquired even since the time of its delivery.

For the above reasons, it is requested to uphold the appeal, to change the decision appealed, to uphold the appeal against enforcement, as it was filed, to cancel the enforcement itself and all enforcement documents drawn up for this purpose, with court fees.

The appellee S.C. E. S.A., by its insolvency administrator, the insolvency company - Casa de insolvență Transilvania, brought statement of defense by requesting the appeal to be rejected as unfounded with the consequence of keeping the appealed decision in its entirety.

In supporting its procedural position, the appellee company states that the appellant's affirmation regarding Civil Decision 1776/02.02.2012 to become irrevocable, at the expiry of the period for making an appeal, cannot be upheld by the court, being applicable in the case the New Civil Procedure Code as regards the enforcement according to Art. 3 paragraph 1 of Law 76/2012.

Regarding the appellant's arguments concerning the illegality of the enforcement documents and the enforcement itself as an effect of the expiry of the limitation period of the undersigned's right to require enforcement, it is considered that they cannot be upheld by the court, stating the following:

First, according to the law, the provisions of the New Civil Procedure Code shall apply both to enforcements initiated after its entry into force and to judgments delivered before its entry into force.

Thus, according to Art. 3 paragraph 1 of Law no. 76//2012 for the implementation of Law no. 134/2010 on the Civil Procedure Code, "the provisions of the Civil Procedure Code shall apply only to processes and enforcements initiated after its entry into force", and according to Art. 5 of the same regulatory document "the provisions of the Civil Procedure Code relating to the enforcement orders shall also apply to judgments or other documents delivered or, as applicable, drawn up before the entry into force of the Civil Procedure Code, which can be enforced even if they did not obtain any declaration of enforceability." Art. 8 of the law in question adds that "as from the entry into force of the Civil Procedure Code, references within regulatory documents to the "final and irrevocable" judgment or, where appropriate, "irrevocable" shall be understood as being made to the "final" judgment."

As can be seen, by Law no. 76/2012 the legislator established the transitional rules on the practical application of principle tempus regit actum under the conditions of coexistence of 


\section{LIMITATION OF THE RIGHT TO REQUIRE ENFORCEMENT UNDER THE RULE OF \\ THE NEW CIVIL PROCEDURE CODE OF AN ENFORCEMENT ORDER OBTAINED BEFORE ITS ENTRY INTO FORCE}

two different laws. Analyzing Art. 3, Art. 5 of Law No. 76/2012, as well as Art. 632 NCPC, it results that, after its entry into force, all enforcements shall be conducted under the new Civil Procedure Code, the enforceability of the order shall be analyzed in relation to the new law including for the orders delivered under the old law. Thus, decision no. 1776/02.12.2012, respectively decision no. 1017/R/02.12.2014 are subject, as regards their legal nature of enforcement orders, to the new procedural rules (Book V, Title I, Chapter II - Enforcement Order, of the New Civil Procedure code).

In this sense, the High Court of Cassation and Justice1 also decided, which, by Decision no. 2144 as at 11.06.20142 established that "(...) in accordance with Art. 5 of Law no. 76/2012 for the implementation of the new Civil Procedure Code, (...) Even if according to Art. $720^{\wedge}$ of the old Civil Procedure Code under which the civil trial was initiated and it was delivered civil decision in question which was enforceable, given the provisions of the new Civil Procedure Code, it results that civil decision (...) is subject to the provisions of the new code. Thus, civil decision (...) is not an enforceable judgment in relation to the provisions of Art. 632 and the provisions of Art. 633 of the Civil Procedure Code."

It is also shown that the New Civil Procedure Code states in Art. 632 that "(1) Enforcement shall be made only pursuant to an enforcement order. (2) There represent enforcement orders the enforcement judgments referred to in Art. 633, judgments with provisional enforcement, final judgments, as well as any other judgments or documents which, by law, can be "enforced", and it sets out in Art. 633 the enforceable judgments: "There are enforceable judgments: 1. the judgments delivered on appeal, unless the law provides otherwise; 2 . the judgments delivered at first instance, without right to appeal, or those in relation to which the parties agreed to exercise directly the appeal, according to Art. 459 paragraph (2)". Hereinafter, in Art. 63 it is stated which are final judgments: "(1) There are final judgments: 1. judgments which are not subject to appeal or recourse; 2. judgments delivered in first instance, with right of appeal, not appealed; 3. judgments delivered in first instance, which were appealed; 4. judgments delivered on appeal, with no right of appeal, and not appealed; 5. judgments delivered on appeal, even if by them is was resolved the case; 6 . any other judgments which, by law, cannot be appealed. (2) Judgments referred to in paragraph (1) become final on the date of expiry of the deadline for exercising the appeal or the recourse or, where applicable, on the date of delivery."

Consequently, Decision no. 1776/02.12.2012 is an enforceable judgment, but it is not final (it became final after the Law Court of Bihor rejected the appeal, on 02.12.2014).

\footnotetext{
${ }^{1}$ The High Court of Cassation and Justice decided that, in accordance with Art. 5 of Law no. 76/2012 for the implementation of the new Civil Procedure Code, the provisions of the new Civil Procedure Code regarding the enforcement orders shall also apply to judgments and other documents delivered, or where appropriate, drawn up before the entry into force of the Civil Procedure Code. Therefore, even if according to Art. $720^{8}$ of the old Civil Procedure Code, under which there began the civil trial, the civil decision in question was enforceable, given the provisions of the new Civil Procedure Code, it results that the civil decision delivered, in this case, in October 2013, is subject as regards its enforcement to the provisions of the new Procedure Code, not being an enforceable judgment (judgment delivered in the first instance and appealed), so that it cannot be upheld the application for suspension of the decision enforcement.

${ }^{2}$ http://www.juridice.ro/347769/iccj-hotarare-executorie-vs-hotarare-neexecutorie.html
} 
In relation to the limitation of the right to obtain enforcement, Art. 705 of NCPC provides that: "(1) The right to obtain enforcement is prescribed within 3 years, unless the law provides otherwise. (...). (2) The limitation period begins as from the date when it is given the right to obtain enforcement. In the case of judgments and arbitrated judgments, the limitation period begins as from the date when they become final", thus when they cannot be attacked anymore. As a result of the provisions stated, the limitation period does not begin when the judgments are enforceable without being final.

Thus, although in the case of judgments and arbitral judgments the right to obtain enforcement is given as from they become enforceable, the limitation begins only from the date when they become final, so from the moment when they cannot be appealed anymore. In this sense, it was also set the doctrinal opinion3 according to which "(...) the creditor - owner of a judgment (...) - is not exposed to the risk of limitation of the right to obtain enforcement if, by caution or for any other reason, it waits the enforcement order to become final."

Also in the sense of the above are the provisions of Art. 637 paragraph 1 of the New Civil Procedure Code stating that "the enforcement of a judgment which is an enforceable order can be made only at the creditor's risk if the judgment can be appealed; if the order is subsequently amended or abolished, the creditor shall be obliged, under the law, to give the debtor its rights, in whole or in part, as appropriate."

The legislator warns the creditor that he may proceed to enforcement in vain, as long as his order is not consolidated by a final judgment.

However, the limitation of the right to obtain enforcement begins only when the judgment becomes final.

Moreover, even the old regulation on the limitation period beginning when it is given the right to obtain enforcement (namely when the decision became enforceable) was also heavily criticized in the specialized literature and it also had echoes in jurisprudence (in the Decision of the Supreme Court of Justice no. 2373/1997, the supreme court ruled that "a judgment that is not final and irrevocable cannot be considered an enforcement order even if it was given with enforceable order (...) and therefore, the judgment not being final, being contested (...) it cannot be enforced)."

In the specialized literature4 it has been shown that "the beginning of the limitation period should not be linked to the enforceability or the enforceability of the judgment, but to its res judicata, since as long as the judgment is not final, and the appellant does not have the certainty of being given the right, the enforcement order is threatened by dissolution in the extraordinary remedies. In addition, the extended length of the trials, especially in the extraordinary remedies before the High Court of Cassation and Justice, can lead to expiry of the limitation period until the appeal is resolved. Under these conditions, the creditor who wanted to be sure of his right, to avoid a possible return of enforcement, is sanctioned by the impossibility to exploit in an enforceable manner the right that was just irrevocably given to him." Therefore, the limitation of the right to require enforcement must always run from the date when the judgment becomes irrevocable.

The appellant's defenses as a whole, are based on the assumption that SC E Oradea SA was obliged to enforce the decision no. 1776/02.12.2012, using a restrictive interpretation of Art.

${ }^{3}$ Gabriel Boroi (coordinator) and the collective, New Civil Procedure Code-comment on articles, Hamangiu Publishing House, Bucharest, 2013, p. 191

${ }^{4}$ Marian Nicolae, Treaty on limitation, Universul Juridic Publishing House, Bucharest, 2010, p. 950 


\section{LIMITATION OF THE RIGHT TO REQUIRE ENFORCEMENT UNDER THE RULE OF \\ THE NEW CIVIL PROCEDURE CODE OF AN ENFORCEMENT ORDER OBTAINED BEFORE ITS ENTRY INTO FORCE}

405 of the Civil Procedure Code of 1865 , according to which the limitation period begins from the date when it is given the right to require enforcement, date which, in this case, according to the appellant, would coincide with the date of delivery of the decision by the trial court.

However, it is stated that at the time of delivery of the decision no. 1776/02.12.2012, the New Civil Procedure Code was not yet in force, so if there had been an obligation to enforce the decision, as regards the limitation period, there would have been applicable the provisions of the old code. Consequently, such an interpretation of the appellant does not explain how it is possible that an irrevocable and enforceable judgment, which has res judicata, however cannot be enforced because it have already limited the right to require enforcement, although the application for enforcement filed by the appellee was recorded at BEJ Gîrdan Marius on 21.08.2015, namely at less than a year after decision no. 1776/02.12.2012 became irrevocable and was delivered by Oradea Law Court in case $8950 / 271 / 2005^{*}$ by rejecting the appeal by Civil Decision no. 1017/R/02.12.2014 delivered by Bihor Law Court in the case with the same number.

By applying the reductio ad absurdum argument of interpretation, it can be seen that the acceptance of the appellant's reasoning leads to unacceptable solutions. For example, an application of a creditor is upheld in part by the trial court by an enforceable judgment, and subsequently the court for judicial control, by a final judgment (irrevocable), upholds in its entirety the creditor's application, but the delivery of the solution of the remedy is on a date that exceeds 3 years from the date of delivery of the trial solution.

By applying the appellant's theory, it would mean that the creditor, although has finally obtained a final and irrevocable enforcement order, with res judicata, is not entitled to use the enforcement procedure except for the debit amount contained in the application upheld by the trial court. However, this is contrary not only to legal principles, but also to any elementary logic.

It is estimated that, for the decision which became irrevocable by the decision of the recourse delivered in 2014, the beginning in 2015 of the enforcement falls within the period of three years provided for in Art. 705 paragraph 1 and 2 of the Civil Procedure Code, republished.

$\mathrm{V}$. Analyzing the appeal in terms of the reasons put forward by the appellant and those of public policy that can be put forward by the court and ex officio, under Art. 476-478 of the Civil Procedure Code, the court of appeal concluded the following:

In essence, the appellant states that the trial court wrongly rejected her application for annulment of enforcement itself, given that the right to request the enforcement of civil decision no. 1776/02.02.2012 was prescribed, at the time of filing the application to the bailiff, in relation to the provisions of Art.706 of the Civil Procedure Code of 1865, according to which the limitation period begins as from the date when it is given the right to obtain enforcement, a right which was given on the date of delivery of civil decision no. 1776 of 02.02.2012, judgment which had an enforceable effect, according to Art. 377 point 1 of the Civil Procedure Code, so that on 21.08.2015 when filing the application to the bailiff, the limitation period of 3 years had expired.

VI. The court of appeal considered the appellant's criticisms to be unfounded.

As also correctly concluded the trial court, the enforcement order on which it is based the application for enforcement of the appellee S.C. E. S.A. is represented by civil decision no. 
1776/2012 of Oradea Law Court by which the court upheld the application for return of enforcement filed by the appellant S.C.E S.A. against many appellees, including also the appellant, and obliged the appellees to reimburse the sums received during January-February 2004 by way of compensation, specifically the appellant to pay the sum of 12651 lei, sum that would be brought up-to-date with the inflation rate on the date of the effective reimbursement. This civil decision became irrevocable by rejecting the appeals of some of the appellees, by civil decision no. 1017/02.12.2014 of the Law Court of Bihor. As results from the provisions and considerations on the record of this decision, the appellant did not exercise the remedy of the appeal against that judgment, having the quality of appellee in the appeal filed by the other employees.

The enforceability of civil decision that represents the enforcement order in question shall be always reported to the law in force at the time of delivery of the decision, according to the principle tempus regit actum, because on the date of delivery of a judgment the holder of the right shall know, in relation to the law in force at that time, if the judgment he holds can or cannot be enforced on the date of its delivery.

Thus, the trial court correctly concluded that civil decision no. 1776/2012 delivered under the Civil Procedure Code of 1865 became final in accordance with Art. 377, paragraph 1, subparagraph 1 and enforceable under Art. 376, paragraph 1, first sentence, on the date of its delivery, namely on 02.02.2012, being a decision delivered in first instance without right of appeal, which could be appealed only by recourse.

Thus, there is no doubt that at the time of delivery of civil decision no. 1776/02.02.2012, S.C. E Oradea S.A. had a clear representation of the fact that it held a final and enforceable judgment that could be enforced without any impediment under Art. 376 in relation to Art. 374 of the Civil Procedure Code of 1865.

The enforceability of a judgment is the one that gives it the enforcement power that is the possibility to be immediately enforced after being given enforceable nature, under the law at the time, of course with the risk, under the law, of the person who enforces the judgment, to be obliged to reimburse the benefits if the court for judicial control changed the judgment in favor of the opposing party.

This risk taken, regulated by law under Art. 379 index 1 of the Civil Procedure Code of 1865, however, is not able to annihilate the final and enforceable nature of a judgment in particular, clearly resulting from the law.

Moreover, in this case there must be taken into account the appellant's specific situation who did not make an appeal in the case and in relation to which civil decision no. 1776/2012 became final on the expiry of the appeal period, under Art. 377 paragraph 2 subparagraph 1 of the Civil Procedure Code.

There was mentioned that it cannot be taken into account the appellee's criticism in respect of a passive procedural co-participation that would have influence over the final and irrevocable nature of the judgment, given that from the provisions of civil decision no. 1776/2012 it is clear that the law court has established for each appellee debtor in part a distinctive debt individualized in the judgment, and for the appellant a concrete sum of 12651 lei, so in relation to her, and to all the other debtors, the company had an individual claim coming from its own right to salary, without between these rights to be any interdependent relationship of solidarity and indivisibility.

Under these conditions, in which the flow due by the appellant was distinctly individualized from the other debtors' flow according to the judgment itself, and it did not exercise the 


\section{LIMITATION OF THE RIGHT TO REQUIRE ENFORCEMENT UNDER THE RULE OF \\ THE NEW CIVIL PROCEDURE CODE OF AN ENFORCEMENT ORDER OBTAINED BEFORE ITS ENTRY INTO FORCE}

remedy of appeal, there was no impediment for the creditor S.C. E S.A. to pursue it in order to make the claim, especially since in relation to this appellee the decision no. 1776/2012 became final and enforceable on the date of its delivery 02.02.2012 and irrevocable on the expiry of the 15-day period for exercising the remedy.

As regards the limitation of the right to require enforcement under Art. 405 paragraphs 1 and 2 of the Civil Procedure Code of 1865, the period is of 3 years and begins on the date when it is given the right to require enforcement.

Clearly, the right to require the enforcement of a judgment arises on the date on which it can be enforced, in the case in question on the date of delivery of civil decision no. 1776/2012, final and enforceable judgment of first instance because it is subject only to appeal.

The enforceability of this decision comes form the law, namely from Art. 377, paragraph 1, subparagraph 1 of the Civil Procedure Code which gives it the value of final judgment and Art. 376, paragraph 1, first sentence of the same code which gives it enforceable nature.

Thus, it is undoubtedly that the time when a judgment becomes enforceable, namely it can be enforced without any legal limitation, overlaps with the time at which begins the limitation period of enforcement of the decision, because as from that time the creditor can be deemed to be passive in relation to its own right.

The fact that in this case the remedy of recourse was judged in 2014, and the judgment became irrevocable, in relation to some of the debtors (but not in relation to the appellant who din not make an appeal in that case), and the beginning of the enforcement by the procedure followed by the bailiff is subject to the provisions of the New Civil Procedure Code according to Art. 24 thereof, as the executor request was filed after the entry into force of this law, shall not have any influence on the enforceability of the judgment which represents an enforcement order, because this character is always taken into account in relation to the law in force on the date of delivery of the judgment and not in relation to a subsequent law, nonexistent on the date of its delivery.

The principle of law predictability requires the beneficiary of a judgment to clearly know on the date of delivery of a judgment whether the judgment in question is enforceable or not and whether it can be immediately enforced, appreciation that must always consider the law of the time, according to the principle tempus regit actum.

Conditioning the enforceability of a judgment and hence the possibility of enforcing it by a subsequent law would represent a law retroactivity, expressly prohibited in Art. 15 of the Romanian Constitution.

It should be understood that the enforceability of a judgment and, therefore, the date from which begins the limitation period for the enforcement, moments that overlap, are closely related to the judgment and its legal status, being previous elements, intrinsic and conditional to trigger the enforcement.

Thus, even if the enforcement of the judgment follows the provisions of the new Civil Procedure Code on effective procedures for enforcement, representing summons and all other acts of the executor, the enforceability of the judgment shall remain closely linked to the law under which it was delivered and can be reported only to that law, namely the Civil Procedure Code of 1865.

It was considered that there cannot be retained in this way the allegations of the trial court which circumstantiates the enforceability or not of a judgment of a preventive behavior of the 
creditor who would not be required to enforce a judgment if it is not irrevocable, because in this way it is illegally added to law.

As long as the law clearly provides by Art. 377 paragraph 1 and Art. 376 sentence I of the Civil Procedure Code of 1865 that the final judgment given without right of appeal is enforceable, any discussion on the enforceability conditioned by the creditor's will becomes useless and ineffective.

Moreover, in the specific case of the appellant debtor, given that it did not exercise the remedy of recourse, and his claim was individual and well-defined in the provisions of the judgment, without being directly related to that of the other debtors, the law court judgment remained even irrevocable within 15 days from its delivery by non-recurrence according to Art. 377 paragraph 1 subparagraph 2 of the Civil Procedure Code, not being at that time any impediment to the enforcement of the debt owed by it.

Therefore, it was specified that the appellant correctly argues that at the time of filing the application for the enforcement of civil decision no. 1776/0.20.2.2012, respectively on 21.08.2015 the 3-year period of limitation of enforcement had expired, according to Art. 405 paragraphs 1 and 2 in relation to Art. 377 paragraph 1 subparagraph 2 and Art. 376 first sentence of the Civil Procedure Code of 1865.

The appellee's statements related to the way in which she would be harmed by such an interpretation cannot be accepted, given that the legal provisions on the date of the judgment delivery were very clear and gave her the right to enforce the judgment, without any restriction.

Moreover, if they felt endangered and wished the suspension of the enforcement of that judgment, the debtors had at hand another procedural means, namely that provided by Art. 300 paragraph 2 of the Civil Procedure Code of 1865, that of requiring in a reasoned way the suspension of the judgment enforcement, a procedural means which, however, the appellant did not have, by not making a recourse, the reasons why, in relation to her the judgment became irrevocable on the expiry of the recourse period, being unable to prove any reasonable legal impediment to prevent the creditor the begin the enforcement against him thereafter.

The appellee's criticism on the applicability concerned of the New Civil Procedure Code cannot be considered as long as the enforceability of the judgment in 2012, and by default the date from which the limitation period begins can report exclusively to the law in force at that time, namely the Civil Procedure Code of 1865.

Also, there cannot be retained any allegations as regards the possibility to enforce a judgment only after it becomes irrevocable, because such an interpretation interferes with Art. 377 paragraph 1 subparagraph 1 and Art. 376 first sentence of the Civil Procedure Code of 1865 which expressly confers enforceable and final nature to the judgments delivered without right of appeal, contested only by recourse.

As a matter of fact, in the case, in relation to the appellant's situation who did not make any recourse against the decision, the enforcement is limited and in relation to the decision which becomes final and irrevocable and which intervened in his case within 15 free days from the date of delivery.

Any theories according to which there are enforceable judgments which are not final do not find their application in the Civil Procedure Code of 1865, and the time when the enforcement limitation begins shall always be related to the date on which the judgment becomes enforceable, mingling with this time; any theory that leads to the disintegration of the two moments does not find its logic in the purpose and the foundation of the two institutions, 
given that the enforceability of a judgment is recognized for an essential purpose, which is to be enforced from the date of delivery, so that the creditor's passivity at this time entitles the limitation beginning with the consequence of the possibility of limiting the right to obtain the enforcement of the decision.

VI. For all these factual and legal reasons, concluding that at the time when it was filed the application to start enforcement at the bailiff on 21.08.2015, the right to request enforcement had already been prescribed under Art. 405 paragraphs 1 and 2 of the Civil Procedure Code of 1865, the 3-year period that began from the date of delivery of civil decision no. $1776 / 02.02 .2012$ expiring on 02.02.2015, the court of appeal concluded that the right to require enforcement is prescribed, reason for which it cancelled the enforcement itself from the enforcement file no. 608/2015 of BEJ Gârdan Marius Florin.

Accordingly, the court of appeal under Art. 480 paragraph 2 of the Civil Procedure Code upheld the civil appeal5 brought by the appellant against the appellee SC E SA against civil decision no. 11107 as at 09.12.2015 delivered by Oradea Law Court that was changed in part, in that: it upheld the appeal to enforcement filed by the appellant against the appellee SC E S.A.; it upheld the objection of limitation of the right to require enforcement; it cancelled the enforcement itself from enforcement file no. 608/2015 of BEJ Gârdan Marius Florin against the appellant debtor.

Under Art. 453 paragraph 1 of the Civil Procedure Code, seeing the appellee's claims, the appellee was obliged to pay the appellant as court fees to the fund and appeal the sum of 800 lei, representing the lawyer's fees, proven with receipt no. 484/19.11.2015 filed in original to the trial court, issued by S.C.P.A. Vântu \& Crișan.

Under Art. 45 paragraph 1, subparagraph f of Government Emergency Ordinance 80/2013 as regards the upholding of the appeal to enforcement by this final judgment, the court ordered to be reimbursed to the appellant the legal stamp duty paid to the trial court amounting to 1000 lei and the stamp tax paid on appeal amounting to 500 lei, the total stamp tax to be reimbursed amounting to 1500 lei.

\section{CONCLUSION}

All in all, the interpretation of the court is based on the next conclusions: any theories according to which there are enforceable judgments which are not final do not find their application in the Civil Procedure Code of 1865, and the time when the enforcement limitation begins shall always be related to the date on which the judgment becomes enforceable, mingling with this time; any theory that leads to the disintegration of the two moments does not find its logic in the purpose and the foundation of the two institutions, given that the enforceability of a judgment is recognized for an essential purpose, which is to be enforced from the date of delivery, so that the creditor's passivity at this time entitles the limitation beginning with the consequence of the possibility of limiting the right to obtain the enforcement of the decision.

${ }^{5}$ Civil Decision no. 331/A/06.04.2016 of Bihor Law Court, delivered in case no. 14721/271/2015, not published 


\section{BIBLIOGRAPHY:}

1. Marian Nicolae, Treaty on limitation, Universul Juridic Publishing House, Bucharest, 2010;

2. Gabriel Boroi (coordinator) and the collective, New Civil Procedure Code - comment on articles, Hamangiu Publishing House, Bucharest, 2013;

3. http://www.juridice.ro/347769/iccj-hotarare-executorie-vs-hotarare-neexecutorie.html. 